\title{
Digital Era Governance - a new chapter of public management theory and practice
}

\section{Wojciech Białożyt}

\begin{abstract}
Digital technologies profoundly influenced social and economic realities, making the world more difficult to govern. These changes reached public administration, including the New Public Management (NPM), a bureaucratic model that evolved from both the new institutional economics and the notion of managerialism, and has been gaining traction in developed countries since the beginning of the 1980s. NPM, which has been based on managerialism, decentralization, de-bureaucratization, privatization and a reduction of size and scope of the administration, passed its peak in the mid-2000s. States have been undergoing a 'hollowing out' process, losing their role of provider of public services and causing increasing citizens' discontent as the NPM has been failing to deliver results. This has coincided with the accelerating development of the notion of governance (Polish: współzarządzanie), a model based on powersharing and the participation of citizens in the co-creation of institutional order and co-design of public services. Such governance, however difficult it may be to define clearly, has, in contrast to NPM, taken into account social phenomena that traditional examinations of government and public administration have overlooked.

This article points out that the transformational role of the internet had a fundamental impact on the relations between governmental institutions and citizens. The internet has accordingly paved the way for the emergence of a new public administration model: Digital Era Governance (DEG) in which digital technologies are in the center of governments' organizational structures. As simple digitization of bureaucratic proceedings has no longer been delivering recognizable results, DEG embraces the permeation of government by the culture of internet. The key features of the Digital Era Governance and its more advanced version - Essentially Digital Governance (EDGE) are reintegration (referring to the architecture of state administration), need-based holism (focusing on citizens' needs) and digitization changes (concerning cultural, social and technological adaptation). DEG and EDGE both challenge public administration, requiring its internal and external opening, and lead to an administrative set-up characterized by simplification, automation of daily bureaucratic work and flexibility in delivering services. While the NPM model still remains strong in many countries, its impact is diminishing and alternative scenarios can be drawn concerning how DEG and EDGE will be entering the practice of government and public administration in the years to come.
\end{abstract}

\section{Introduction}

The digital revolution has in the previous decade become an immanent part of human existence, disrupting it in a fundamental way. The world has become chaotic and more difficult both to understand and to govern while the relationships between citizens and states have undergone a substantial change.

This transformation has also impacted the theory and practice of public management, highlighting, as never before, the outdated character of the Weberian model of public administration that is still operational in many countries worldwide as well as the exhausted potential of the New Public Management (NPM). Following the digital revolution and posteconomic crisis austerity policies, NPM, which has had a major influence on the theory and practice of public management, has met its limits of development. At the same time, the notion 
of governance has emerged, marking the opening of a new chapter of public management in which cooperation between the public administration and citizens plays a critical role. Accordingly, the most advanced form of governance - digital era governance - is gaining momentum with digital technologies as a central element.

These trends - the digitization of all spheres of life coupled with social transformations and followed by new dimensions of public management - are irreversible and interlinked while happening at different paces. This results in the need to implement a new holistic public management architecture to respond to tensions between digitally savvy citizens who are becoming increasingly demanding and the public administration, still working under the rules of former models.

\section{From the Weberian model to the New Public Management}

The $20^{\text {th }}$ century has been marked by the domination of two major bureaucratic models: the Weberian one and the New Public Management (NPM). The former featured formalism, vertical hierarchies, limited communication channels and has been particularly resistant to the influence of the external world. At the turn of the 20th century, it was at origin of the Progressive Era Public Administration (Hood 1995 ) that was based on three main elements: idealization of civil servants' careers separated from the labor market, limits imposed on civil servants' discretion and equal treatment of citizens based on the rule of law.

This system evolved in the second half of the 20th century from the classic model of public administration based on strict procedures, imperative relations between the government and public services' recipients towards public management that included relations with citizens as part of broadened coordination networks. It was followed by managerialism that, along with new institutional economics, originated at the turn of the 1970s and 1980s with the emergence of New Public Management. Developed in the United Kingdom, NPM was quickly embraced by the USA, New Zealand and Australia, and other OECD countries followed (Gruening 2001).

New Public Management is defined by five main features (Hays Kearney 1997): reduction of size and scope of the administration, managerialism (bringing business models to public administration), decentralization (bringing the decision - making process closer to citizens), de-bureaucratization (focus on the outcomes, not processes) and privatization (outsourcing of services and supplies to private companies). Other key elements of NPM employed in various countries in different forms are: disaggregation of large organizational units, implementing competition and incentives to the public sector based on business examples. Borins (1995) has pointed out that NPM consist of a number of interlinked elements based on: "providing high quality services that citizens value; increasing the autonomy of public managers; rewarding organization and individuals on the basis of whether they meet demanding performance targets; making available the human and technological resources that managers need to perform well; and appreciative of the virtues of competition, and maintaining an open minded attitude about which public purposes should be performed by the private sector, rather than a public sector." 
Dunleavy (Dunleavy et al. 2005) pointed out three pillars of the New Public Management structure:

- Disaggregation - dividing large organizational public administration structures so as to make internal structures flat and eventually to change the management systems (a process similar to those implemented by corporations). This was followed by enhanced flexibility in human resources management, IT contracting, public tendering which altogether brought a new management structure and a new system of information circulation needed to coordinate complex management operations,

- Competition - separating purchasers and providers of public services which allowed to differentiate supply modes and triggered increased competition among suppliers,

- Incentivization - implementing incentives systems for civil servants on the basis of their performance.

Throughout the 1980s and 1990s New Public Management became a well-developed and coherent theory of management change based on a conviction that public sector organizations should embrace organizational benchmarks deriving from the private sector. One of the NPM doctrine's underlining features has been that the public sector enjoys a monopolistic position and does not include any incentive for productivity improvement. That is why NPM assumed that the public sector could become more effective in allocating resources by absorbing tools used in the private sector (Ehsan, Naz 2003). This particular element of NPM thinking has been shaping public administration since the early 1980s until the early 2000s.

The first signs of NPM losing its momentum emerged in the 1990s with public policy failures, in particular in countries where NPM was most developed, such as the United Kingdom (Dunleavy, Margetts 2013). States have been undergoing a 'hollowing out' process, losing their role of provider of public services. This was caused by a number of elements: privatization processes and a decrease in the scope of state intervention, excessive agencification and a weakening position of the civil service. In developed countries, where NPM has reached the highest levels of implementation, the introduction of private suppliers into delivering public services has turned out to be too expensive in the course of time. The governments that needed to cut public spending the most diminished the scopes of consultancy projects by limiting them in size and by renegotiating contracts.

The underlying aim of the New Public Management which was to bring savings in public expenses has therefore failed to be achieved. The economic crises that hit developed countries in the previous decade and the austerity policy that followed put pressure on corporate management - the NPM feature imported from business (Dunleavy, Margetts 2013). Cuts in the public sector also put an end to audits (Power 1994) that were originally designed to continuously track the institutions' and civil servants' performance.

By contrast to these trends, a few examples of countries that sought savings by contracting private suppliers can be pointed out - e.g. in the case of Greece outsourcing was used as a tool to limit the excessive powers of labor unions. 
In the course of time, some NPM characteristics ceased to coincide with the trends emerging in modern societies. As Vigoda (2002) indicated, today's public administration must absorb tensions caused by the need for increased responsiveness to citizens as clients and effective collaboration with them at the same time. While responsiveness - one of NPM's features - is mostly perceived as passive, unilateral reaction to requests, cooperation is a more proactive, two-sided engagement by both citizens and public administration. The latter element was clearly missing in the practice of New Public Management.

Although the Weberian model has been undergoing significant transformation in the previous century, of which NPM can serve as proof, its essence remains still in conflict with the nature of collaboration which entails cooperation, participation, negotiation and unlimited information circulation. As Frederickson put it, mutual dependencies among government, public administration, citizens and third parties are becoming a strategic goal of modern democracies on their path towards achieving a new quality of public management (Frederickson 1997).

Most public management researchers share a view that NPM has passed its peak. Some authors (Dunleavy, Margetts 2013) have been pointing out that NPM has been dead intellectually since the mid-2000s. But the discussion continues about what NPM stagnation means for public management in countries where it has been holding a dominant position - in Anglo-American ones and in some parts of Europe, such as Scandinavia and Holland. NPM's deadlock does not necessarily means its disappearance - in a number of countries that are still under the influence of the Weberian paradigm, it can even be developing further. In some countries, such as Japan or India, NPM is still gaining traction, given that the whole generation of policy makers and civil servants has been extensively trained to work under this model.

Researchers examining the impact of digitization on public management find that NPM created a fragile, not agile model of state in which a lack of institutional stability undermined its ability to learn and to keep institutional memory (Dunleavy, Margetts 2015). New Public Management has proved not to be responsive enough to the digital revolution and social changes related to it. NPM does not offer any kind of participation in or co-creation of the public sphere other than voting in elections or being a consumer of the delivered public service. This inability by the NPM to make a next step in its development paved the way for a new phase in the theory of public management - governance.

\section{Governance to respond to the polycentric society}

At the beginning of the 70s, Harlan Cleveland pioneered in promoting the notion of governance as an alternative to public administration (Frederickson 2004); his message was: less government, more governance. Cleveland was pointing out: "The organizations that get things done will no longer be hierarchical pyramids with most of the real control at the top. They will be systems - interlaced webs of tension in which control is loose, power diffused, and centers of decision plural (...). These new style public-private horizontal systems will be led by a new breed of man and 
women. I call them Public Executives, people who manage public responsibilities whether in 'public' or 'private' organizations. (They will be guided by) a sense of welfare; a sense of equity; a sense of achievement; and a sense of participating."

In accordance to the "less government, more governance" approach, the notion of "centerless society" emerged (Rhodes 2006) while at the same time states had become increasingly governed in a polycentric way (Kooiman 1993, 2003). The governments' goal in the polycentric model is to enable the broadest possible public and social interactions and for public responsibilities to be managed by various agents on the grounds of cooperation, partnership and co-ownership. This model could be implemented on both local, national and international levels. What distinguished government from governance is, according to Rosenau, that government relates to acts based on formal power while governance to acts based on common goals.

Following the work of H. Cleveland, governance was promoted at the turn of the 1970s and 1980s, according to Jerzy Wilkin, by representatives of institutional economics, including Oliver Williamson (Wilkin 2013). As Cleveland indicated, governance is based on powersharing, includes participation of 'subordinates' in the co-creation of institutional order, highlights their pro-activeness and engagement. In this model, those who have power share it with 'subordinates' in the common interest. In Poland, the term wspótzarzadzanie has been coined by Jerzy Hausner as best fitting the English original, governance (particularly when it refers to the public sphere).

The increasing role of governance in the theory and practice of public management triggered a discussion about the relevance of this term which, according to some researchers, has a strongly intuitive character (Frederickson 2004). As a result, a definition of governance is missing and the term could be perceived as unclear - one may ask whether it refers to the organizational structure of public administration, administration processes, management evaluation, incentive systems, administrative philosophies or maybe is the combination of all these elements. This doubt has been reflected in the literature where a number of meanings of the term governance can be found, including: governance as a retreat from the bureaucratic state to the third-party government (Milward, Provan 2000, Salamon 2002, Frederickson 1997, Rhodes 1997 ), governance as development of social capital, civic society, a high level of civic participation (Hirst 2000, Kooiman 2001, Sorensen 2003), governance as a new public management and managerialism (Kernaghan, Marson, Borins 2000, Considine, Painter 1997 ), governance as how the public sector works (Heinrich, Lynn 2000), governance as a structure of political institutions (National Research Council 1999), governance as interinstitutional cooperation and network management (Frederickson 1999, O'Toole 2003, Peters, Pierre 1998), governance as globalization and rationalization (Pierre 2000), governance as corporate supervision, transparency and accountability (Monks, Minow 2004, Jensen 2000, Blair, MacLaury 1995), governance as Tony Blair's third way - a political toolbox of new public management ideas, extended forms of civic participation, attempts to renew the civil society (Newman2001), governance as the way in which governments get things done (Frederickson 2004). 
An interesting angle for describing governance has been proposed by Rhodes (2006) who coined the notion of governing without government. Rhodes stated that the state being hollowed out was to be replaced by a new, uneasy to classify form of government: "Governance based on self-organizing networks will challenge governing abilities as networks are autonomous and resistant to top-down management. They become first examples of governing without government."

As Frederickson (2004) indicated, most features attributed in the literature to the term governance - networks and cooperation among units and individuals of different formal and legal status - are forms of institutional adaptation serving to meet the globally increasing interdependencies between people and organizations. This change of relations among governments, institutions of civil society, local governments and other actors involved in facing the problems of the public sphere has also been flagged as a core part of the notion of governance by Wilkin (2013). As he indicated, governance is about creating institutional order in which economic and other forms of human activities are conducted.

Employing governance to characterize how states function also has, as in the case of economic organizations, an efficiency dimension. In this respect, it is not only about implementing decisions that have been made but about doing it effectively, i.e. bearing in mind the input and output ratio. The efficiency of public expenditure policies currently constitutes an important element of governments' legitimacy while it is still effectiveness which plays a dominant role in this respect.

A distinguishing mark of institutional structures working under the governance model is that they improve the efficiency of organizations or economic entities mostly because they generate positive impulses (to engage, to innovate, to change) and allow to make the most of the dispersed knowledge embodied in organizations and people in a certain place and time (Wilkin 2013).

With the increase of importance of governance in the theory of public management, critical voices are also being raised that undermine the significance of the changes it brings (Frederickson 2004). According to Strange (1983), governance is a simple replay of old academic discussions in a new attractive form. He indicated that while governance is becoming trendy, it does not deliver too much added value to discussions concerning public administration and that some academics, especially in Europe, use governance to overvalue their research projects. Others pick up the argument that the term governance is unclear and too broad and it is difficult to assign any particular meaning to it. There are voices, too, that governance has an emotional dimension - positive assessments of governance are due to anti-bureaucratic and anti-government sentiments and an aversion to limited government (Kernaghan, Marson, Borins 2000, Osborne, Gaebler 1992). It has also been raised that governance, rather than focus on core aspects of governmental systems, often concentrates on institutions that are not truly forming the public administration, i.e. non-governmental organizations, external suppliers - in short, on third parties.

Jessop flagged another issue that makes it difficult embrace governance: to the problem of finding an equivalent word in languages other than English. This problem applies to Poland, too. While a unified translation of governance is missing, it seems that the most 
relevant expression in Polish to reflect governance has been proposed by Jerzy Hausner who proposed wspótzarządzanie or, in a narrower meaning, wspótrządzenie (Oramus 2015).

Despite this overall criticism, governance is undoubtedly an important term in the modern discussions about the future of public administration, particularly in the light of the emergence of forces and social phenomena that traditional examinations of politics, government and public administration are unable to embrace and explain. It follows the fact that new economic and social problems, including new ways of online communication, are often disrupting traditional legal frameworks. Governance is hugely important due to the serious incompatibility of legal systems on the one side and social, technological, political and economic on the other (Frederickson 2004). The transformation of public management towards governance was partly triggered by the economic crises and the austerity policies.

Despite all its imperfections, governance constitutes the best response to the newly emerging social and economic environment. But to meet criticism that is being formulated, governance-focused researchers need to coin a unified definition. It needs to cover all the relevant aspects while not being too broad. This means that the definition, while describing what governance is, needs also to indicate what it is not.

In the struggle between New Public Management and governance concerning which one can best respond to modern challenges, it was a digital revolution that boosted the latter.

\section{The emergence of Digital Era Governance}

In line with digital technologies stepping in into every single aspect of the human life, a significant part of the population is changing the way it acts socially, economically and politically, with major consequences for the interactions between citizens and public administration.

The social effects brought by the internet and social media lead to far-reaching social, cultural and technological transformations (Dunleavy, Margetts 2013). In the social sphere new concepts and phenomena have emerged, such as: organizing without organization (Shirkley 2008), democratization of innovations (von Hippel 2005), crowdsourcing (Hove 2006), wikinomics (Tapscott, Williams 2006), cognitive surplus (Shirkey 2010). They are increasing the pressure on government and administration to change the nature of their relations with citizens with a focus on nodality in social and information networks (Escher et al. 2006 , Hood and Margetts 2007), allowing both sides to co-create public services.

This specific organizational culture is infiltrating the government and undermining old procedures. It is driving public administration into a new reality as the simple digitization of old bureaucratic models no longer works.

Since the 1990s and speeding up after 2000, the development of online public services has been influencing New Public Management. At the early phase of digital technologies (first computers, information and network systems), governments have often played the role of leaders in implementing new systems and applications (Margetts 1999) although this has 
not had a transformational effect on the whole system of public management. As Dunleavy indicated (Dunleavy, Margetts 2013), digital technologies have not played any significant role after their initial implementation in public administration. In fact, IT operations have been outsourced to agencies and IT companies, pushing technologies out of administration.

What distinguishes the transformational role of the internet is its fundamental impact on various spheres of relations between governmental institutions and citizens and civic organizations. The expansion of the internet not only brings a technological effect, but also delivers a broad range of behavioral, cognitive, organizational, political, cultural changes related to the digital revolution. The internet made a difference as it has been absorbed by individuals and social organizations in a way that enabled them to act quickly and often in a more effective way than state organizations. The internet and mobile technologies accordingly made co-production and co-creation of public services possible on a scale that could not have been envisaged by the pioneers of the notion of governance back in the 1970s (Dunleavy, Margetts 2015).

The way the internet impacts public administration has two dimensions: the individual and the collective. In the former it brings a form of isocratic ("do it yourself") administration where citizens manage public services in the way they now use online banking. In the latter, citizens co-create public services where they use government as a platform of ideas (the concept of a government as a platform) to co-create public policies. But despite the fact that the culture of internet and the system of values it delivers has a significant impact on the internal organization of government, digital environments of governments and citizens still remain significantly unmatched (Dunleavy, Margetts 2015).

It is in this very context that in the mid-2000s the concept of Digital Era Governance (DEG) emerged as a model of public management containing the whole set of internetrelated changes and a central role of digital technologies. The fact that DEG embraced multidimensional social changes differentiated it from the New Public Management (Dunleavy et al. 2005).

The concept of the Digital Era Governance is a subject of PhD research conducted by the author of this article at the Faculty of Economic Sciences, University of Warsaw, under the supervision of prof. Krzysztof Opolski.

The impact of digitization on governance within the model of Digital Era Governance can be analyzed from three perspectives:

- Reintegration - key DEG-related opportunities for the amelioration of public service lie in the reversal of fragmentation of public services that characterized NPM. Reintegration is however not a simple restoration of former centralization, it is rather a non-prescriptive and partly synthetizing response to NPM that leads to a simplification of processes and a decrease in costs,

- Needs-based holism - simplification and a change of relations between the public administration and citizens. A need for broader and more inclusive administrative areas results with a comprehensive transformation of processes, elimination of unnecessary elements, such as compliance costs, formal documentations etc. These changes result in 
an agile state which is capable of flexibly and quickly reacting to changes in the social environment,

- Digitization changes - absorption of digitization leads to delivering public services fully online (an agency becoming its website) without intermediaries (zero-touch technologies).

DEG is not about any kind of technological determinism (Dunleavy, Margetts 2013) the three DEG pillars have an organizational character which refers to the architecture of state administration (reintegration), focusing on citizens' needs (needs-based holism) and including cultural and social technology adaptation (digitization).

A DEG government acts in the build-and-learn mode, co-creating public policies and services in cooperation with citizens. The model also embraces feedback from citizens and takes it into account while delivering public services, making top-down administration irrelevant. Such processes are embodied in each phase of the system, allowing citizens to co-create public services effectively. It is the United Kingdom that is particularly advanced in conducting similar processes (Randomized Controlled Trials) in public administration thanks to its Behavioral Insights Team. Singapore is also trying to catch up with the UK in this respect (Dunleavy, Margetts 2015).

The increasing need for reintegration is also linked to austerity policies implemented by numerous governments in developed countries. Shared services and digital by default tools can be seen here as a means of achieving better policy results while using fewer resources, and of encouraging citizens to manage affairs on their own (Dunleavy, Margetts 2015).

DEG and its more advanced version - EDGE (Essentially Digital Governance) - are bureaucratic models where technologies eventually gain a central place in the organizational structure of governments and public administration (Dunleavy, Margetts 2013). They embrace practices and cultures arising from internet-related beliefs and ideas such as open source, digital rights, and even cyberanarchism and cyberutopism. Such a system of public management is linked to social changes in the same way in which learning is linked to experiencing on the individual level.

Essentially Digital Governance is based on two pillars (Dunleavy, Margetts, 2015) - the first one, focused on establishing a framework for the administration and public service design, includes the following rules::

- Deliver public services for free,

- Use already existing digital information,

- Do it once,

- Grow scalable services in competition,

- Isocratic (DIY, do it yourself) administration.

The second pillar provides a normative framework for policy-making and service delivery:

- Value equality of outcome over process,

- Provide formal rights and real redress,

- 'Keep the state nodal' obligation,

- Experiential learning. 
The development of EDGE is being limited by Weberian and New Public Management models still enjoying a dominant position in public administration practice. Some governments, mostly in Anglo-Saxon countries, are making an effort to catch up with citizens who are immersed in the digital world and use social media and online discussion platforms not only as a first source of information but also a more credible one than public administration in its current bureaucratic form. But a lack of sufficient expertise results in governments being unable to be connected to citizens and, as a result, losing their confidence (Dunleavy, Margetts 2015).

The discussion about whether and how quickly DEG and EDGE could be implemented continues among practitioners and researchers influenced by New Public Management (Dunleavy et al., 2005). While DEG partly reverses someNPM elements, it still refers to NPM. Accordingly, one of the scenarios being discussed is the emergence of a digital version of New Public Management which could be only selectively embracing DEG. There is a risk, however, that in this option reintegration of administration structures could rather lead to staff reductions and in this way could not tackle the vertical agency silos. This could lead to the questioning of DEG-related transformation and improvement of public services. Another risk is that that politicians and policy makers start implementing simultaneously contradictory elements of DEG and NPM. It cannot be also ruled out that policy makers, trained in the NPM model, would be implementing DEG so slowly that the distance between modernization processes and government institutions could deepen further.

Question marks concerning DEG implementation are also being formulated by organizations advocating for strict privacy rules when storing and using large amounts of personal data (Dunleavy et al. 2005). Also, centralization/de-centralization and agencification/ de-agencification phases could be interpreted by some as inevitable cycles, and not as a fundamental and irreversible change in public management practice.

DEG must be followed by the internal and external opening of governments leading to a much less complicated institutional and political set-up characterized by simplification, automation of daily bureaucratic work and flexibility in delivering services. This is due to the fact that, in the modern world, public administration operations need to be closely linked to the increasing autonomous capabilities of citizens in self-management of problems in social spheres.

\section{Conclusions}

In many countries, government structures and operations still resemble the 19th-century model characterized by collecting paper documentation. In some countries current systems of public administration are an "eclectic mix" of the Weberian model with elements of New Public Management and Digital Era Governance (Dunleavy, Margetts 2015). Since the 2000s the bureaucratic models in which digital technologies are at their centers are becoming reality but there is no certainty whether a full implementation of Digital Era Governance is possible. 
Impulses to make the Digital Era Governance a true paradigm of public sector reform are likely to come from the external world and from public opinion pressure. Similarly to the neo-classical economic model which is in retreat following the recent financial and economic crises, New Public Management is no longer a sufficient tool to deliver public services in today's world - it is unable to meet citizens' expectations. In some countries - such as Poland - where New Public Management has been only partly implemented, the inevitable challenge will be how to transform public administration towards the DEG/EDGE models.

Modern administration that is partly being based on the Weberian and partly on the NPM model will be experiencing mounting pressures from the general public and its transformation into the DEG model can only be seen as a question of time.

\section{Bibliography:}

Dunleavy, P., 2014, The State is a Multi-System: Understanding the Oneness and Diversity of Government, paper at the 2014 UK Political Studies Association Conference, Manchester, 15 April 2014.

Dunleavy, P., Margetts, H., 2013, The Second Wave of Digital Era Governance: a quasiparadigm for government on the web, "Philosophical Transactions of the Royal Society A", 371(1987).

Dunleavy, P., Margetts, H., 2015, Design Principles for Essentially Digital Governance, Conference paper, paper at the 111th Annual Meeting of the American Political Science Association, San Francisco, 3-6 September 2015.

Dunleavy, P., Margetts, H., Bastow, S. and Tinkler, J., 2005, New Public Management is dead. Long live Digital-Era Governance, "Journal of Public Administration Research and Theory", 16 (3), pp. 467-494.

Dunleavy, P., Margetts, H., Bastow, S. and Tinkler, J., 2008, Digital Era Governance: IT Corporations, the State and e-Government. Revised Edition, Oxford: Oxford University Press.

Ehsan, M., Naz F., 2003, Origin, Ideas and Practice of New Public Management: Lessons for Developing Countries, Asian Affairs, Vol. 25. No. 3: 30-48, July-September, 2003.

Frederickson, H.G., 2004, Whatever Happened to Public Administration? Governance, Governance Everywhere, Institute of Governance, Public Policy and Social Research, Belfast: Queen's University. 
Gruening, G., 2001, Origin and theoretical basis of New Public Management, “International Public Management Journal", 4 (2001), pp. 1-25.

Hausner, J., 2008, Zarządzanie publiczne, Warszawa: Wydawnictwo Naukowe SCHOLAR

Howe, J., 2006, “Crowdsourcing: A Definition". Crowdsourcing Blog.

Oramus, M., ,2015, Model współzarządzania (governance) i problemy dotyczące jego

wdrażania w administracji publicznej, „Rocznik Administracji Publicznej”, 2015 (1).

Osborne, D., Gaebler, T., 1992, Reinventing Government, Addison-Wesley Publ. Co.

Rhodes, R. A. W., 2006, The New Governance: Governing Without Government, "Political Studies", 44(4), pp. 652-667.

Shirky, C., 2011, Cognitive Surplus: How Technology Makes Consumers Into Collaborators, Penguin Group

Tapscott, D., Williams, A. D., 2006, Wikinomics, New York: Penguin Group.

Vigoda, Eran, 2002, From Responsiveness to Collaboration: Governance, Citizens, and the Next Generation of Public Administration, "Public Administration Review", September/ October 2002, Vol. 62, No. 5.

Wilkin, J. (ed.), 2013 Jakość rządzenia w Polsce. Jak ją badać monitorować i poprawiać?, Warszawa: Wydawnictwo Naukowe SCHOLAR. 


\section{Od modelu weberowskiego do nowej fazy zarządzania publicznego - współzarządzania ery cyfrowej}

\section{STRESZCZENIE}

Technologie ccyfrowe wywarły znaczny wpływ na realia społeczne i ekonomiczne, czyniąc rządzenie jeszcze trudniejszym niż dotychczas. Zmiany te wpłynęły również na administrację publiczna, w tym na New Public Management (NPM, Nowe Zarządzanie Publiczne), model zarządzania publicznego który powstał na bazie nowej ekonomii instytucjonalnej i menedżeryzmu, i który szybko rozwijał się w krajach rozwiniętych od początku lat 80. XX wieku. Nowe Zarządzanie Publiczne, które oparte było na ograniczeniu rozmiarów i zakresu działania administracji, menedżeryzmie, decentralizacji, odbiurokratyzowaniu i prywatyzacji usług publicznych osiągnęło szczyt swojego rozwoju w połowie lat 2000. Państwa zaczęły doświadczać zjawiska „wypłukiwania” kompetencji, tracąc rolę dostarczyciela usług publicznych, co wywoływało społeczne niezadowolenie, podczas gdy NPM traciło pozycję efektywnego modelu zarządzania publicznego. Zjawisko to zbiegło się w czasie z rozwojem governance (współzarządzania), modelu opartego na włączaniu obywateli we współtworzenie porządku instytucjonalnego i usług publicznych. Jakkolwiek pojęcie governance jest trudne do precyzyjnego zdefiniowania, obejmuje ono, w przeciwieństwie do NPM, zjawiska społeczne, których tradycyjne sposoby badania zarządzania publicznego i administracji publicznej nie biorą pod uwagę.

Poniższy artykuł opisuje, jak transformacyjny efekt internetu wpłynął w sposób fundamentalny na relacje pomiędzy instytucjami publicznymi a obywatelami. Efekt ten utorował również drogę do rozwinięcia się modelu Digitial Era Governance (DEG, Współzarządzania Ery Cyfrowej), w którym technologie znalazły się w centrum rządowych struktur zarządczych. Podczas gdy prosta cyfryzacja dotychczasowych usług publicznych przestała przynosić zauważalne efekty, model DEG zawiera nie tylko narzędzia cyfrowe, ale też funkcjonuje w zgodzie z kulturowymi zmianami jakie niesie internet. Kluczowymi cechami modelu DEG i jego bardziej zaawansowanej wersji EDGE (Essentially Digital Governance) są reintegracja (odnosząca się do konstrukcji administracji publicznej), zorientowanie na potrzeby odbiorców usług i zmiany cyfrowe (obejmujące adaptację technologiczną, społeczną i kulturową zmian cyfrowych). Tak DEG i EDGE podają w wątpliwość dotychczasowy sposób działania administracji publicznej, wytwarzając presję na jej wewnętrzne i zewnętrzne otwarcie w kierunku uproszczenia, automatyzacji codziennej pracy administracji i elastyczności w dostarczaniu usług publicznych. Podczas gdy model NPM nadal odgrywa istotną rolę w praktyce zarządzania publicznego, w wielu krajach, jego znaczenie maleje i wejście DEG i EDGE do praktyki zarządzaniu publicznego można widzieć w najbliższych latach w kilku scenariuszach.

Wojciech Białożyt is think-tank professional and public policy manager. He serves as Managing Director of Warsaw-based WiseEuropa think-tank. He conducts PhD research at the Faculty of Economic Sciences, University of Warsaw, focusing on impact of digitization on the public management models

Autor jest Dyrektorem Zarządzającym warszawskiego think-tanku WiseEuropa. Jest słuchaczem studiów doktoranckich na Wydziale Nauk Ekonomicznych Uniwersytetu Warszawskiego; w swojej pracy badawczej koncentruje się na wpływie cyfryzacji na zarządzanie publiczne. 